\title{
Acanthamoeba, bacterial, and fungal contamination of contact lens storage cases
}

\author{
Trevor B Gray, Ray T M Cursons, Jane F Sherwan, Paul R Rose
}

\begin{abstract}
Background-Microbial corneal infection is the most serious complication of contact lens wear. Contact lens cases are a recognised potential source of pathogens associated with corneal ulcers.

Methods-This survey established the incidence of protozoal, bacterial, and fungal contact lens case contamination in 101 asymptomatic daily wear cosmetic contact lens wearers from a domiciliary contact lens practice.

Results-Eighty two (81\%) contact lens cases were found to be contaminated, with $19(19 \%)$ sterile. Of all contact lens cases, $78(77 \%)$ grew bacteria, 24 (24\%) fungi, and $20(20 \%)$ protozoa. Acanthamoeba spp were isolated from eight $(8 \%)$ contact lens cases. Fifty six (55\%) contact lens cases yielded mixed bacterial contamination. This is the first contact lens case survey in which hydrogen peroxide disinfection was the major method of contact lens disinfection (75\% of subjects) and no home made saline was used. All the contaminating organisms were shown to possess the enzyme catalase that breaks down hydrogen peroxide to oxygen and water. The polymicrobial nature of the biofilms found in many contact lens cases is illustrated electron micrographically. Conclusion-Based on data from this and previous studies, the authors conclude with recommendations for contact lens wearers: (1) regular scrubbing of contact lens case interior to disrupt biofilms; (2) exposure of contact lens case to very hot water $\left(\geqslant 70^{\circ} \mathrm{C}\right)$ will kill Acanthamoeba contaminants; (3) allow contact lens case to air dry between uses; (4) if hydrogen peroxide disinfection is preferred, use a two step system; (5) replace contact lens case regularly.

(Br f Ophthalmol 1995; 79: 601-605)
\end{abstract}

Contact lens wear is now the most prevalent risk factor for new cases of corneal ulcers at Moorfields Eye Hospital. ${ }^{1}$ Although Pseudomonas aeruginosa is the most important microbial cause of contact lens associated keratitis, other bacteria, fungi, or Acanthamoeba may also cause this condition. ${ }^{12}$ To what extent lens hygiene systems contribute to this condition has been the subject of debate. ${ }^{3-6}$ Although there have been many documented cases of identical bacterial strains being isolated from an infected cornea and the contact lens case used before infection ${ }^{48}$ recent evidence regarding extended wear contact lenses suggests that there may be no correlation between contact lens hygiene and bacterial keratitis. ${ }^{1}$ Insufficient data exist for acanthamoebae to draw a similar conclusion. It has been suggested that co-contamination of contact lens care systems with acanthamoebae and bacterial species capable of supporting amoebic growth may be the first step in the pathogenesis of Acanthamoeba keratitis by the provision of large inocula of amoebae. ${ }^{9} \mathrm{We}$ recently described a case of Acanthamoeba keratitis in a disposable lens wearer in which a lack of lens hygiene and co-contamination of the contact lens case with both bacteria and acanthamoebae was noted. ${ }^{10}$ Because contact lenses may be an important vehicle for the transfer of amoebae from contaminated contact lens cases to the cornea, we undertook a survey of the microbiological quality of the contact lens cases from asymptomatic daily wear cosmetic contact lens wearers. Particular note was made of the lens hygiene systems being employed and their relative effectiveness in preventing or inhibiting microbial colonisation of the contact lens case.

\section{Subjects and methods}

\section{SUBJECTS}

One hundred and one consecutive contact lens wearing clients attending a domiciliary optometry practice were recruited. They had each used contact lenses for more than 6 months, had no eye disease, and were cosmetic contact lens wearers. Before their annual checkup visit, each client was offered a free new contact lens case in exchange for presenting their old one. They were only informed of the contamination survey at the contact lens case exchange. Most of the recruitment occurred during the winter months.

The following information was recorded: client age, sex, occupation, length of contact lens use, contact lens material, type of wear (daily, extended, or occasional), disinfectant, saline, and cleaner. The clients were asked to describe their contact lens disinfection and cleaning routine, their compliance with proprietary recommendations was assessed as complete compliance, minor faults (for example, no hand washing), or major faults (for example, no disinfectant used). Presence of clinical symptoms (for example, redness, irritation) and signs (for example, conjunctival hyperaemia) was documented. No accurate determination of the period of time that the contact lens case had been in use could be made because few clients could remember accurately. 
LABORATORY METHODS

Contact lens cases were coded and batched before being sent to the laboratory where they were opened under aseptic conditions. Laboratory staff had no access to the clinical data detailed above. Any fluid found remaining in the case was discarded. A sterile, unpreserved saline moistened cotton wool swab was rubbed over all internal surfaces and the swab tip placed in a sterile bijou container. A total of $4 \mathrm{ml}$ sterile saline was added to the contact lens case and then shaken vigorously. This solution was transferred to the bijou containing the swab tip. The bijou contents were mixed using a vortex for 10 seconds, and divided for bacterial, fungal, and amoebal studies.

\section{BACTERIAL ISOLATION}

Using a standard $5 \mu \mathrm{l}$ bacterial loop, the lens case solution was cultured onto $5 \%$ Columbia blood agar and MacConkey agar plates and incubated in air at $30^{\circ} \mathrm{C}$ for 3 days. After incubation all lactose fermenting and non-lactose fermenting Gram negative bacilli were identified to the genus level using a series of manual biochemical tests. ${ }^{11}$ These tests included; oxidase, motility, oxidation/fermentation, citrate, methyl red, indole, Voges-Proskauer, and growth on MacConkey agar. Catalase was assayed qualitatively using hydrogen peroxide as outlined in the Manual of Clinical Microbiology.11 Gram positive bacteria were identified by their characteristic colonial morphology and Gram stain appearance. No attempt was made to further speciate bacteria.

\section{FUNGAL ISOLATION}

A $0.5 \mathrm{ml}$ aliquot of the lens case solution was cultured onto an SAC slope (Sabouraud dextrose agar+chloramphenicol $0 \cdot 1 \%+$ gentamicin $0.4 \%$ ) and incubated in air at $27^{\circ} \mathrm{C}$. Cultures were incubated for 14 days before being discarded as negative. Positive cultures were identified by microscopic and macroscopic morphology.

\section{AMOEBAL ISOLATION}

A $1.0 \mathrm{ml}$ aliquot of the contact lens case solution (as prepared above) was cultured on a Pages amoeba saline (PAS) agar plate which had previously been spread with a lawn of heat killed ( $65^{\circ} \mathrm{C} / 30$ minutes) Escherichia coli. ${ }^{11}$ The plates were incubated in a humidified chamber at $30^{\circ} \mathrm{C}$ for up to 7 days, and examined every 48 hours. Cultured amoebae were identified as

Table 1 Contact lens case disinfectants used by clients in the survey

\begin{tabular}{lrl}
\hline Product & No & Active ingredient \\
\hline Aosept (Ciba Vision) & 70 & Hydrogen peroxide ('one step') \\
Oxysept 1 and 2 (Allergan) & 6 & Hydrogen peroxide ('two step') \\
Soaclens (Alcon) & 12 & Thiomersal \\
Bausch \& Lomb Multi-purpose solution & 3 & Polyaminopropyl biguanide 0.00005\% \\
Optifree (Alcon) & 2 & Polyquad \\
Boston Lens & 2 & Chlorhexidine \\
Clean-n-Soak (Allergan) & 1 & Phenylmercuric nitrate + propylparabens \\
Boil-n-Soak & 1 & Thiomersal \\
Duraclean (Allergan) & 1 & Anionic amphoteric surfactants \\
Hydrocare (Allergan) & 1 & Thiomersal \\
\hline
\end{tabular}

Table 2 Contact lens cleaning solutions used by clients in the survey

\begin{tabular}{lr}
\hline Product & No \\
\hline Polyclens II (Alcon) & 40 \\
Miraflow (Ciba Vision) & 36 \\
Softmate (Barnes Hind) & 5 \\
L.C.65 (Allergan) & 5 \\
Sorbiclean (Allergan) & 4 \\
Soft Mate (Barnes Hind) & 2 \\
Bausch \& Lomb Multi-purpose solution & 2 \\
Oxyclean (Allergan) & 1 \\
Pliagel (Alcon) & 1 \\
Boston Lens & 1
\end{tabular}

either Acanthamoeba or other free living amoebae by morphology of cyst, flagellate, and trophozoite stages.

\section{STATISTICAL ANALYSIS}

Treatment groups were compared by $\chi^{2}$ analysis using Fisher's exact test for significance where cell size was small.

\section{Results}

A total of 101 clients (75 female and 26 male) participated. The median age was 32 (range 12-65) years, with the median length of contact lens use being 6.0 (range $0.5-29$ ) years. Eighty six $(85 \%)$ patients wore soft contact lenses while the remainder wore hard lenses. Three patients used disposable soft contact lenses (each used a daily wear cleaning and disinfection regimen with monthly lens disposal). There was no extended wear use of soft contact lenses.

\section{CONTACT LENS HYGIENE}

Ninety nine $(98 \%)$ clients used proprietary disinfecting solutions (see Table 1) while two $(2 \%)$ clients used no disinfecting solution. Ninety eight $(97 \%)$ patients used proprietary contact lens cleaning solutions (see Table 2), two clients used no contact lens cleaner, and one was unrecorded. Full compliance with recommended disinfection and cleaning practice was recorded in $61 \%$, minor compliance errors (for example, no hand washing) in $28 \%$, and major compliance faults (for example, no disinfection/cleaner) in $11 \%$. No patient used homemade saline. No heat disinfection units were used. There were no overt clinical infections in any of the patients, though many of the contact lens cases were observed to have obvious biofilms (see Fig 1).

\section{MICROBIAL CONTAMINATION}

The results show a significant degree of microbial contamination in the contact lens cases presented for analysis. Eighty two $(81 \%)$ were contaminated with microbes, leaving only 19 (19\%) sterile. Twenty four (24\%) contact lens cases were colonised by fungi and $20(20 \%)$ by protozoa. Those recorded as having major compliance faults did not have significantly higher rates of contact lens case contamination than those who described full compliance with recommended contact lens hygiene. There was no significant difference in contact lens case 


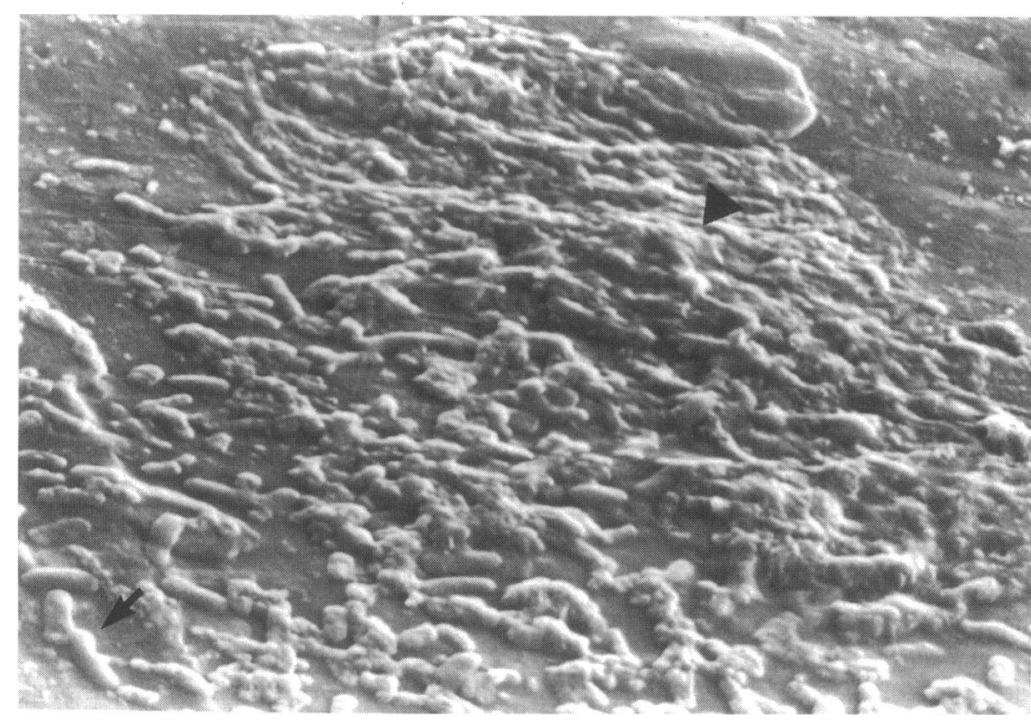

Figure 1 Scanning electron micrograph demonstrating microbial biofilm formation (arrowhead) in a used contact lens case, individual bacteria (arrow) are also seen $(\times 3115)$.
Table 4 Level of microbial contamination seen with peroxide and non-peroxide disinfection methods (22 protozoal contaminants were cultured from 20 contact lens cases)

\begin{tabular}{lll}
\hline Contaminant & $\begin{array}{l}\text { Hydrogen peroxide } \\
\text { disinfection (\%) }\end{array}$ & $\begin{array}{l}\text { Non-peroxide } \\
\text { disinfection (\%) }\end{array}$ \\
\hline No contamination & $11 / 76(14)$ & $9 / 23(39)$ \\
Multiple bacterial spp & $33 / 76(43)$ & $5 / 23(22)$ \\
Fungi & $21 / 76(28)$ & $3 / 23(13)$ \\
Protozoa: & $18 / 76(24)$ & $4 / 23(17)$ \\
$\quad$ All spp & $5 / 76(7)$ & $3 / 23(13)$ \\
\hline
\end{tabular}

\section{DISINFECTANTS}

Seventy six $(75 \%)$ clients used hydrogen peroxide disinfectants and $23(23 \%)$ clients used cold non-peroxide chemical disinfection systems (see Table 1). Relative numbers of organisms isolated with the different systems are given in Table 3. There was no significant difference between the two hydrogen peroxide systems used in the degree of disinfection attained.

Two clients used no disinfection system. In neither case were the contact lens cases grossly contaminated nor were Acanthamoeba spp or fungi cultured. Each grew a single Gram negative isolate (Alcaligenes sp, Acinetobacter sp).

Statistical analysis demonstrated that, with the exception of Acanthamoeba spp, the nonperoxide systems were associated with less microbial contamination $(p<0.05)$.

(eventy eight $(77 \%)$ contact lens cases bacteria (see Table 3). Notable by their absence were Staphylococcus epidermidis and Staphylococcus aureus. Most (56/78) (72\%) of the culture positive contaminated contact lens cases had mixed bacterial contaminants.

\section{FUNGAL CONTAMINATION}

There were 24 fungal contaminants, the majority growing Cladosporium spp (10/24) or Candida spp (9/24). Other fungi isolated were Fusarium solani, Aspergillus versicolor, Exophiala spp, and Phoma sp. Most fungi were isolated in association with bacteria but on three occasions, fungi were the only microbes isolated.

\section{PROTOZOAL CONTAMINATION}

There were 22 protozoan contaminants isolated from 20 containers, eight being Acanthamoeba spp, four Naegleria spp, four Vahlkampfia spp, two Hartmannella spp, three flagellates, and one ciliate. All protozoa were isolated in conjunction with bacteria and eight had fungal co-contamination.

Table 3 Bacteria cultured from contact lens cases (total number of positive cultures was 78)

\begin{tabular}{|c|c|c|c|}
\hline & $\begin{array}{l}\text { Culture } \\
\text { positive }\end{array}$ & & $\begin{array}{l}\text { Culture } \\
\text { positive }\end{array}$ \\
\hline $\begin{array}{l}\text { Non-fermentative } \\
\text { Gram negative: } \\
\text { Pseudomonas spp } \\
\text { Xanthomonas spp }\end{array}$ & $\begin{array}{r}47 / 78 \\
2 / 78\end{array}$ & $\begin{array}{l}\text { Coliforms: } \\
\text { Serratia spp } \\
\text { Klebsiella } \\
\text { Citrobacter }\end{array}$ & $\begin{array}{r}19 / 78 \\
2 / 78 \\
1 / 78\end{array}$ \\
\hline $\begin{array}{l}\text { Other Gram negative: } \\
\text { Alcaligenes spp } \\
\text { Acinetobacter spp }\end{array}$ & $\begin{array}{l}20 / 78 \\
11 / 78\end{array}$ & $\begin{array}{l}\text { Gram positive: } \\
\text { Diphtheroids } \\
\text { Micrococcus } \\
\text { Bacillus }\end{array}$ & $\begin{array}{l}9 / 78 \\
1 / 78 \\
1 / 78\end{array}$ \\
\hline
\end{tabular}

\section{Discussion}

Corneal infection is the most common vision threatening complication of contact lens wear. Organisms isolated from contact lens associated corneal ulcers have often been shown to be identical to those isolated from the contact lens case, 4810 making the contaminated contact lens case a possible replenishable source of pathogenic microbes. In spite of the apparent adherence to recommended cleaning and disinfecting regimes, a significant degree of microbial contamination of contact lens cases was found in this study. Many of the contaminants identified were potential pathogens and as such should have been prevented by the disinfectant regimen used.

No single reason could be ascertained for the failure of the contact lens care systems although many contact lens cases were observed to contain obvious biofilms (Fig 1). The adherence of microbial biofilms onto plastic surfaces and their relative resistance to antibiotics and antiseptics has been reported. 5612 These biofilms may have been responsible for disinfectant failure by providing a continuous seed inoculum.

All microbial contaminants (amoebae, bacteria, and fungi) isolated from the contact lens cases contained the enzyme catalase. This enzyme breaks down hydrogen peroxide to water and oxygen. Continued long term use of hydrogen peroxide may have selected a naturally resistant population of microbes adapted to survive repeated exposure to $3 \%$ outermost layers of a biofilm are susceptible to biocides and may release their intracellular hydrogen peroxide. Organisms existing in the 
contents (including catalase) on disruption of their cell membrane by hydrogen peroxide. This released catalase may neutralise local hydrogen peroxide activity, protecting other organisms living deeper within the biofilm. This suggestion requires further investigation.

The $81 \%$ incidence of contact lens case microbial contamination found in this study is higher than rates of contamination found in other similar studies: $42 \%$ in southwest England, ${ }^{13} 46 \%$ in California, ${ }^{5}$ and $53 \%$ in Scotland. ${ }^{14}$ This difference may relate to the age of contact lens cases (affording more time to develop biofilms) in our study, climatic and environmental factors, as well as differences in microbial culture techniques. Unlike these surveys, this study included fungal culture, revealing a $24 / 101(24 \%)$ contamination rate. Other surveys have reported fungal contamination rates of $7 \%$ and $9 \%$ respectively. ${ }^{3} 15$

The most common microbial contaminant isolated in descending prevalence were bacteria $(78 \%)>$ fungi $(24 \%)>$ protozoa $(20 \%)$. Nearly all contact lens cases had mixed microbial populations. The most common bacterial contaminants isolated were non-fermentative Gram negatives followed by coliforms, other Gram negative, and Gram positive organisms.

This study confirms that Acanthamoeba contamination of contact lens cases is far more common than Acanthamoeba keratitis. The $8 \%$ incidence of contact lens case contamination with Acanthamoeba in this study compares with the $7 \%$ in southwest England ${ }^{13}$ and 3\% $(6 / 178)$ in Scotland. ${ }^{14}$

Bacterial co-contamination of contact lens cases growing Acanthamoeba is a common feature of this and other contact lens case contamination studies. ${ }^{1314}$ Acanthamoeba organisms display selective bacterial feeding, particularly non-fermentative Gram negatives and coliforms. ${ }^{9}$ It appears that not all nonfermentative Gram negatives are equally supportive of acanthamoebae. Pseudomonas aeruginosa (the commonest bacterial cause of microbial keratitis) has been shown to produce a toxin which is highly lethal to Acanthamoeba castellanii and Acanthamoeba polyphaga, thus these two eye pathogens may be selectively exclusive. ${ }^{16}$

Three per cent hydrogen peroxide disinfection systems were the most commonly used system in this study $(75 \%$ of contact lens cases). It is interesting that change from other chemical disinfectants to hydrogen peroxide has been widely recommended with the belief that hydrogen peroxide provides greater protection. ${ }^{5}$ This is the first contact lens case contamination survey in which the majority $(75 \%)$ of contact lens wearers used hydrogen peroxide disinfection and none used home-made saline (a reputed major source of contact lens case contamination). While exposure for 2 hours or more to $3 \%$ hydrogen peroxide will kill Acanthamoeba cysts and trophozoites, the 'one-step' system (used by $70 \%$ of the studied subjects) employs a catalyst to neutralise the hydrogen peroxide. In vitro study of 'one-step' systems has shown that the exposure to the 3\% hydrogen peroxide is too brief to effectively kill
Acanthamoeba cysts. ${ }^{17}$ If hydrogen peroxide disinfection is preferred, the authors recommend a two step system in which a properly timed chemical neutralising agent allows amoebicidal (and bactericidal) exposure to hydrogen peroxide.

This survey highlights that there is a need for improvement in contact lens case hygiene. Current contact lens disinfection methods do not appear to be providing a desirable level of microbial protection.

\section{Recommendations to contact lens wearers}

From this and previous data, the authors suggest the following measures should result in less contact lens case and contact lens contamination; thereby possibly reducing the risk of microbial keratitis.

(1) To disrupt accumulated disinfectantresistant microbial biofilms from internal surfaces of the contact lens case, regularly scrub all internal surfaces with a clean cotton bud moistened with contact lens cleaner.

(2) Regular (for example, fortnightly/ monthly) contact lens case heat disinfection by placing open contact lens case into a container (for example, mug) and filling the container with very hot water (1 minute of exposure to $\geqslant 70^{\circ} \mathrm{C}$ moist heat will kill all Acanthamoeba cysts and trophozoites ${ }^{18}$ ). First establish that the contact lens case material can withstand hot water exposure.

(3) Leave contact lens case open to air dry after heat disinfection.

(4) If hydrogen peroxide disinfection is the preferred regime, use a two step hydrogen peroxide system.

(5) Of course: wash hands before handling contact lens cases; homemade saline never to be used.

(6) Replace the contact lens case regularly. The use of 'disposable contact lens cases' is likely to make points (1) and (2) less important.

The authors thank the Waikato Medical Research Foundation for their financial support. Some of the replacement contact lens cases were kindly donated by Alcon NZ.

1 Dart JKG, Stapleton F, Minassian D. Contact lenses and other risk factors in microbial keratitis. Lancet 1991; 338: $650-3$.

2 Dart JKG, Seal DV. Pathogenesis and therapy of Pseudomonas aeruginosa keratitis. Eye 1988; 2: 546-55. Donzis PB, Mondino BJ, Weissman BA, Bruckner DA. Microbiol contamination of contact lens care systems. Am Ophthalmol 1987; 104: 325-33.

Mayo MS, Schlitzer RL, Ward MA, Wilson LA, Ahearn DG. Association of Pseudomonas and Serratia corneal ulcers with use of contaminated solutions. $\mathcal{F}$ Clin Microbiol 1987; 25: 1398-400.

5 Wilson LA, Sawant AD, Simmons RB, Ahearn DG Microbial contamination of contact lens storage cases and solutions. Am f Ophthalmol 1990; 110: 193-8.

6 Wilson LA, Sawant AD, Ahearn DG. Comparative efficacies of soft contact lens disinfectant solutions against microbial films in lens cases. Arch Ophthalmol 1991; 109: 1115-57.

7 Chalupa E, Swarbrick HA, Holden BA, Sjostrand J. Severe corneal infections associated with contact lens wear. Corneal infections associated

8 Mayo MS, Cook WL, Schlitzer RL, Ward MA, Wilson LA, Ahearn DG. Antibiograms, serotypes, and plasmid profiles of Pseudomonas aeruginosa associated with corneal ulcers and contact lens wear. $\mathcal{f}$ Clin Microbiol 1986; 24: $372-6$.

9 Bottone EJ, Madayag RM, Qureshi MN. Acanthamoeba keratitis. Synergy between amoebic and bacterial co-contaminants in contact lens care systems as a prelude to infection. f Clin Microbiol 1992; 30: 2447-50. 
10 Gray TB, Gross KA, Cursons RT, Shewan J. Acanthamoeba keratitis. A sobering case and a promising new treatment. Aust NZ $₹$ Ophthalmol 1994; 22: 73-6.

11 Hendrickson DA, Krenz MM. Reagents and stains. In: Balows A, Hausler WI, Herrnann KL, Isenberg HD, Shadomy HJ, eds. Manual of clinical microbiology. 5th ed. Washington DC: American Society for Microbiology, 1991; chapter 122: 1285-314.

12 Anwar H, Strap JL, Costerton JW. Establishment of aging biofilms: possible mechanism of bacterial resistance to antimicrobial therapy. Antimicrob Agents Chemother 1992; antimicrobial

13 Larkin DF, Kilvington S, Easty DL. Contamination of contact lens storage cases by Acanthamoeba and bacteria. $\mathrm{Br} \mathcal{F}$ Ophthalmol 1990; 74: 133-5.

14 Devonshire P, Munro FA, Abernethy C, Clark BJ.
Microbial contamination of contact lens cases in the west of Scotland. Brf Ophthalmol 1993; 77: 41-5.

15 Pitts RE, Krachmer JH. Evaluation of soft contact lens disinfection in the home environment. Arch Ophthalmol 1979; 97: 470-2.

16 Qureshi MN, Perez AA, Madayag RM, Bottone EJ. Inhibition of Acanthamoeba species by Pseudomonas aeruginosa: rationale for their selective exclusions in corneal ulcers and contact lens care systems. $\boldsymbol{f}$ Clin Microbiol 1993; 31: 1908-10.

17 Silvarny RE, Dougherty JM, McCulley JP, Wood TS, Bowman RW. The effect of currently available contact lens disinfection systems on Acanthamoeba castellanii and Acanthamoeba polyphaga. Ophthalmology 1990; 97: 286-90. 18 Kilvington S. Moist heat disinfection of Acanthamoeba cysts. Rev Inf Dis 1991; 13: 418 